\title{
The Library in the 21st Century: Transformation in Romania
}

\author{
By Radu Alexandru Tonca*
}

\begin{abstract}
This research paper aims to analyze Romanian contemporary Libraries in their relationship with small communities, highlighting the impact that institutions may have in their cultural and social sphere and to theorize the concept of the "Open Library" and all that means transformation in the last decades, both in terms of form and their role in the community. The central idea of this paper is to dissect the relationship between the Library and the readers/community and to discuss or discover various ways through which one can achieve and "open" fruitful attitude and involvement. This discussion analyzes how the contextual sphere of the reading process itself has changed over time and we speak of a triad: reading-book-readers, a relational triangle that forms a foundation for the Library. Analyzing the relationship between the Community and the Library is important in the context of digitization and virtualization of books and information, as one must find solutions for a healthy relationship, collaboration and education. When we speak of the library of the XXI century, we think of the image of a glass box, perfectly transparent, very accessible located in the heart of the city/neighborhood. Today, its role goes far beyond the one it had only one or two centuries ago and is no longer enough for the library to be open and to wait for the reader, it must be a catalyst for both the cultural life of the community and the development of each of its members.
\end{abstract}

\section{Introduction}

A big problem of libraries today in Romania is that they are facing a serious shortage of spaces, which gives rise to a full suite of other problems and which can be the germ of deep discussions about the power of libraries in communities, the power of attraction, the power of education, the level of openness towards the needs of its citizens, the capability of generating platforms for public debates, free talks or talks focused on local issues and about a libraries' capacity to assimilate the information flushes which abound in all directions in all its forms. In the context of the political-economy of the country, we don't think that we can speak of optimistic forecasts that concern the support that these institutions would receive in the next few years or even in the next few decades. We think, however, that it is important to mention the paradoxical phenomenon that defines the image of libraries in Romania, especially in small and medium cities, namely that libraries (led, mostly, by

${ }^{*}$ PhD Student, Technical University of Cluj-Napoca, Romania. 
dedicated people of culture) are trying to match the European trends of modernization and revolution through sustained activities, through the continuous training of their personnel and the involvement, in some degree, in the life of the communities. However, they do not have proper spaces in which to carry out all these. Libraries become modern and open minded in attitude but their architecture stays the same. This leads to a typical solutions, adaptations and compromises, which are absolutely necessary and justified, but we have to ask ourselves questions like: Today's library must be a meeting and socializing PLACE, but is it necessary that this place would have a physical correspondent, a material, accurate, and fixed one? Could it be possible that this PLACE existed only in collective consciousness, generated and maintained by the will and the energy transmitted by the library? Could this PLACE take different forms - from a street or a market space, to the space of a cafe, of an art gallery or even of a building of offices or another public institution? Some talk about nomadic architecture, the architecture that is forced to walk after the man who leads a dynamic life, dictated by globalization and by liberalization of the labor markets. Is it possible to speak of nomadic architecture for libraries, in situations where nomadic character would be dictated by the physical and material constraints? Is it possible to speak of several places or more locations where the library could "happen" continuously or only sometimes? Or is it possible to speak of hybridization or of a symbiotic program of library architecture with totally different other programs, such as restaurants or bars? And we are not talking of simply inserting a bar, restaurant or cafe somewhere in a corner of the library, but of a total combination of both of them, which would result in a restaurant where one could also read or a library where one could also eat.

All these questions can be channeled into two directions: that of the relationship Library-Community and that in which current dilemmas of the library will be explored and atypical spatial and functional solutions, specific ones and adapted to the context, will be discussed.

\section{Modern Library - Searching its Form and its Purpose}

When we are talking about the modern library of the twenty-first century, we are talking about a complex program that is extremely far away from the dark ages edifice, for example. About the libraries of Antiquity we know that they were big 'sanctuaries', keepers of information, stored on clay tablets or papyrus, and accessible only to the privileged classes. The edifice of the Middle Ages has something dark, something forbidden and dangerous, as the historical period itself is culturally dominated by the power of the Church and its implicit philosophy of good and evil, spirituality and knowledge. Knowledge is often seen as a carrier or the trigger of evil. In "The Name of the Rose", Umberto Eco presents the fortress-library as a maze of traps that protects hidden treasures, untouched, accessible only to the initiated ones. The 
library is governed by the laws of the forbidden, of silence and of a hidden way of communication and enlightenment. ${ }^{1}$

From the library of the Middle Ages, up to that of total transparency and information explosion of today, there was a breakthrough with small steps through several stages. The library of the seventeenth century is aware of the power of knowledge and it allows the profane reader access to its information stock. The library of the eighteenth century is strongly influenced by the ideas of Enlightenment, but also by the economic and scientific developments that led to the setting up of new mentalities. ${ }^{2}$ Juergen Habermas talks about the concept that defines a new mentality and a new social order: the bourgeois public sphere. He analyses the development of the bourgeois public sphere, in western countries, in the eighteen century and the early nineteenth century and then the decline of it. With the rise of the bourgeoisie and the development of a liberal constitutional order, it also developed the public opinion. The bourgeoisie began to understand the role that it played in society and began to rethink a system, based on non-industrial capitalism and liberal political vision. Then, Habermas analyzes the major changes of the second half of the nineteenth century and the early twentieth century, the emergence of a new modern mass society characterized by consumer capitalism. This will lead to the destruction of the bourgeois public sphere and will also change the notion of public opinion, given the increasingly strong influence of the media and political manipulation attempts. In this light, the public information role of the libraries is becoming more and more important. ${ }^{3}$

The public library of the nineteenth century, a century marked by strong emergence and development of spaces and public institutions (museums, public gardens, etc.), is better inserted in society and assumes the primary role of training and education. The twentieth century library nuances and diversifies its own activity and increases its active role in community life. The emergence of various sports events, tourism development, the explosion of new forms of leisure and especially television, as an alternative access to information and leisure activities, lower the library's importance in people's lives and bring these institutions to a relative decline or crisis. So, new strategies are found to attract the public and target new categories, like the blind, the disabled, the unemployed, etc. ${ }^{4}$

The twentieth century brought a succession of major changes for libraries. Four years after the establishment of UNESCO, the 'Public Library Manifesto', in which the public library is called a 'living force in popular education service', was launched. ${ }^{5}$ The UNESCO program intended to arouse the interest in culture and continuing education, as well as people's willingness

1. Umberto Eco, Numele Trandafirului (Bucharest: Polirom Press, 2014).

2. James W. P. Campbell, The Library: A World History (Chicago: University of Chicago Press, 2013).

3. Juergen Habermas, The Structural Transformation of the Public Sphere. An Inquiry into a Category of Bourgeois Society (Cambridge: The MIT Press, 1991).

4. Campbell, The Library: A World History.

5. Mircea Regneala, UNESCO şi accesul mondial la documente şi informaţii (Bucharest: National Institute of Information and Documentation, 1996). 
to defend freedom of expression and to be involved constructively in public life. The new society, after the end of World War II, begins to put a high value on the idea of democracy, community, civic life and then the library becomes important, as an institution that educates the public. ${ }^{6}$ In the year of 1972 the Manifesto is being reviewed and we are talking about the library as a "Living force in the service of education, culture and information and as indispensable tool in the development of international peace and understanding". ${ }^{7}$ It is also about ensuring the access to information for everyone, focusing on categories such as children, elderly or disabled. The last version of this Manifesto is the one from 1994, in which, the public library is considered a portal to knowledge ("The public library, the local gateway to knowledge"), the place where all types of knowledge and information are easily accessible to everyone, regardless of sex, age, religion, nationality, social status, etc.

The extension of the library's missions has resulted in recent decades to its involvement in the life of the local communities, so much that it helps citizens to find jobs, providing information about the labor market and facilitating meetings with bidders. In many countries local authorities were involved in resolving the crisis of libraries. In Denmark the libraries pay particular attention to elderly or disabled people, persons deprived of liberty or the ill and hospitalized ones. In Copenhagen, for example, is assured service at home for older people. In other situations, like Salamanca, the library came out in the public space in order to attract readers, with stalls in the market, near the ones with fruits and vegetables. ${ }^{8}$

The $20^{\text {th }}$ century brings a new mentality. In terms of spatial conception of libraries, reading halls become less dominant and it begins a process of rethinking the importance granted to the various functional areas, resulting in the opening and democratization of the libraries. ${ }^{9}$

Far from the medieval "edifice", the modern library has changed, not only in mission but also in shape and spaciousness (see Figure 1 (a) and (b) for contemporary and medieval library examples). The design gave up the hierarchy of spaces and it adopted a 'democratic' layout, where free access to shelves, highlight individual freedom. ${ }^{10}$ The open libraries of contemporary architecture, far from the hermetical medieval building, but also from the monumental decorated libraries of the eighteenth century or the nineteenth century, are turning to a more intimate scale of the spaces, to small, diverse and specialized rooms, towards comfort, flexibility, functionality and versatile spaces.

6. Gheorghe Buluta, Civilizaţia Bibliotecilor (Bucharest: Encyclopedic Press, 1998), 34.

7. Unesco official website: http://bit.ly/1KZcMTf.

8. Buluta, Civilizaţia Bibliotecilor, 19.

9. Edward Brian and Biddy Fisher, Libraries and Learning Resource Centres (Oxford: Reed Educational and Professional Publishing Ltd, 2002).

10. Gerard B. McCabe and James R. Kennedy, Planning the modern public library building, Gerard B. McCabe and James R. Kennedy editors (Libraries Unlimited, 2013). 

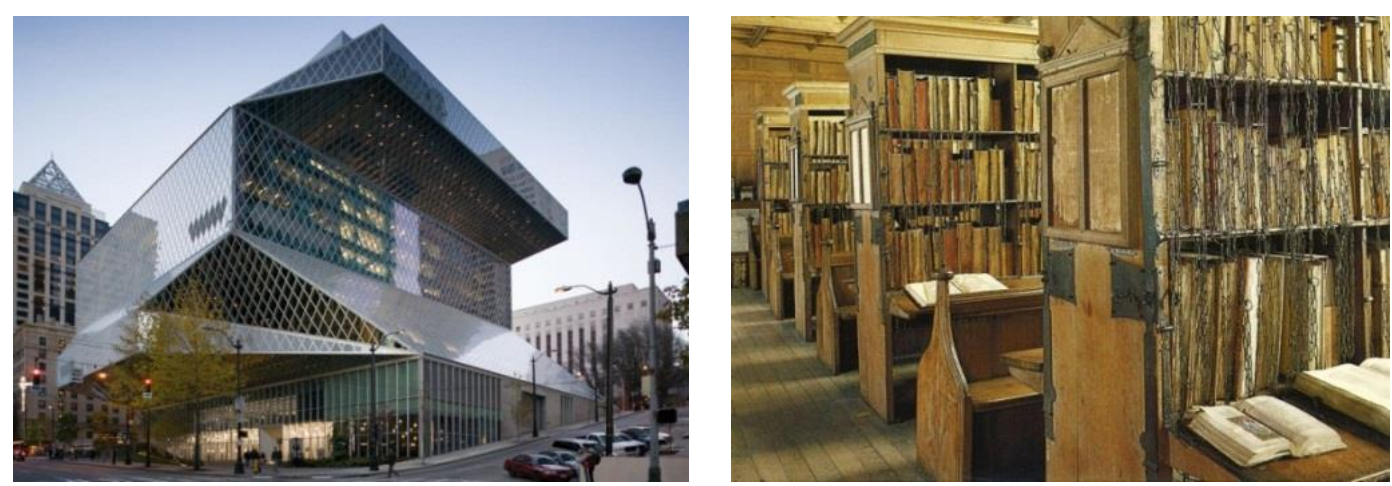

Figure 1. (a) Seattle Public Library, Designed by OMA (Office of Metropolitan Architecture)/Rem Koolhaas Seattle, Washington Source: http://bit.ly/1196gED.

(b) The Chained Library at Hereford Cathedral Source: http://bit.ly/1NfpEpR.

The basic function of the library, a repository of book, turns into a place of the exchange of information. At the same time the library is less and less a place of self-study and increasingly one of working and studying together. ${ }^{11}$

As we said, the explosion of new media entertainment and attractions, movie theaters, individual TVs and more recently the Internet, somehow lowered the power of attraction and the need of libraries. Thus, with the beginning of the $20^{\text {th }}$ century, an extensive and profound process of transformation of these institutions begins. The first sign of change appears in France, where, at the beginning of the $20^{\text {th }}$ century, in the year of 1906 the "L'Association des bibliothécaires françai" is born. During the same period, Eugène Morel (1869-1934), a notorious librarian at the National Library, publishes two articles on the qualities of the modern library, called "Bibliotheques", in 1908 and "La Librarie Publique", in 1910, after visiting London and the USA, discussing the issue of a stronger orientation of libraries towards the public, through specific services addressed to readers, free access to shelter and the adequate training of librarians. In 1911, Morel will introduce the Dewey Classification System in France and will set up the first library for children in Paris. ${ }^{12}$

Another prominent figure of the time, in the library world, is Henri Lemaitre (1881-1946), which discusses the problem of adaptation of libraries to the specific needs of the communities and brings the concept of "bibliobus" to France.

Librarian Henri Lemaître has dealt all his life with the improvement of the ways to spread information easier and he was a militant in the development of two new sectors in librarianship, other than the traditional ones: public reading

11. Fred Lerner, The story of libraries - from the Invention af Writing to The Computer Age, (New York: Continuum Press, Librarie of the Future, 2009), 202-211.

12. Gheorghe Buluta, "Apariţia şi dezvoltarea bibliotecilor," in Tratat de biblioteconomie (Bucharest: Librarians Association of Romania, 2013), 160. 
and documentation. He builds a school for librarians and he is the creator of the first prototype of French "bibliobus" (see Figure 2 for "bibliobus"). This idea is practically taken from the Americans. The system set up a circulating library, which would reach into areas lacking opportunities, like rural areas, but not only. The system was adopted by England, which called it the 'Country libraries'. Lemaître presented "bibliobus" first concept at a conference in Algiers, but was found listening only after another series of exhibitions. Eventually all his achievements converge on one: to facilitate access to information and knowledge for everyone. ${ }^{13}$

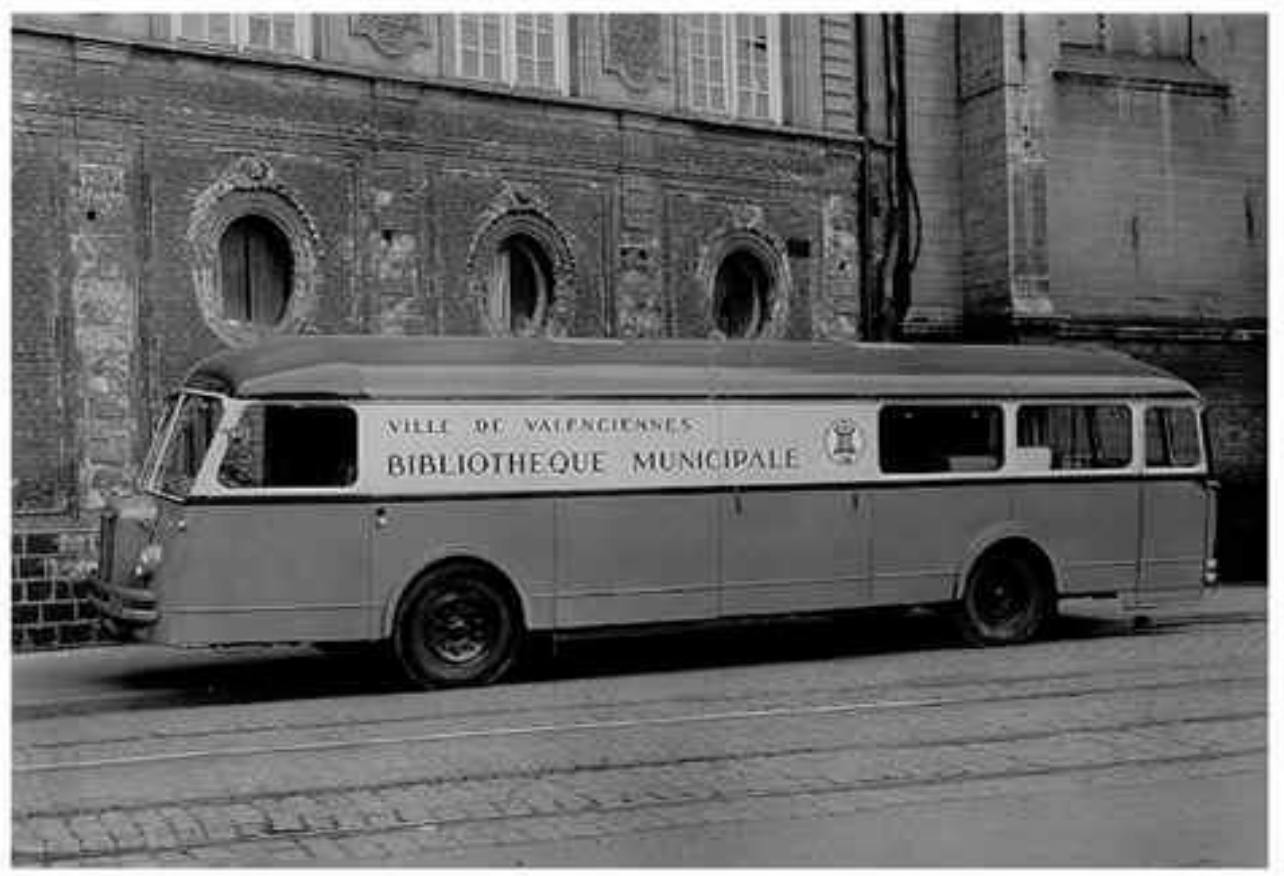

Figure 2. First "Bibliobus", in Valenciennes City, France, 1964 Source: http://bit.ly/1QfvfBM.

At the beginning of the twentieth century, libraries encounter a series of difficulties. The development of economy and the cultural flourishing, thanks to the progress made by civil societies, made the issue of particular specializations topical. The evolution of technology and labor rigors of production or services required accurate and current information, for both workers and researchers. At that time, the need of accurate and current infodocumentary sources was something that libraries could not meet. Libraries had some very restrictive hours, greatly restricting the access to the information available, especially for working people. ${ }^{14}$

13. Nathalie Magne, Henri Lemaître 1881-1946 De la lecture publique á la documentation, Mémoire réalisé sous la direction de Mme Sylvie FAYET-SCRIBE (Paris: Université Panthéon Sorbonne, 1995).

14. Ibid. 
Eventually, at the beginning of this century, libraries were only used by the intellectual elite of the time, Françoise Hecquard even called them "museums of books". 15

Later, the Reconstruction and the postwar reforms, the new social policies and the restructuring of the education system will create the right context for the establishment of new libraries. The library is called in the twentieth century an "instrument of democracy" and the state and local communities are those who are dealing with their establishment and maintenance.

After the 1990s, the new technologies of communication and Information (NTCI) appeared. They governed the world and thus also affected the world of libraries.

The audience that attended libraries became more and more diverse, mainly as a result of the democratization of the institution. Most of the new public, besides researchers and intellectuals, visited the library, less for reading, information or training, but more for leisure. This change of the public and its preferences brought the need of a change in the conception and construction of libraries. Thus, the rooms were designed in such a way so that free access to shelf insured a higher flow of people, and there were projected areas intended for groups of people and provided ramps and elevators to ensure access everywhere for persons with disabilities. Mixing several functions became obligatory, so spaces as conference rooms, coffee shops, large areas or rooms for lectures and workshops merged seamlessly with the library spaces.

In general the entire spatial concept and layout was designed to attract and retain the visitor, to create a pleasant and comfortable atmosphere, opposed to the one of austerity, specific to the last century libraries.

\section{The Romanian Libraries}

In Romania, libraries have had a slow evolution over the centuries, up to the beginning of the 19th century, they still remained, one way or another, related to the ecclesiastical world. Until the 12th century the existence of libraries on the territory of Romania can only be presumed. It is very likely that the existing monasteries or places of worship have also had a small library. In the 12th century, a century marked by the flourishing of religious orders, there are a few certificates, as for example the monastery of "Igriş". The monastery, a subsidiary of a Cistercian monastery from Potigny, France, owned a library. The following centuries will not bring major changes, libraries will develop slowly and modest, always related to monasteries and churches, or, later, to schools established by the Church. ${ }^{16}$

15. Francoise Hecquard, La Formation des Bibliothécaires: L'enseignement de l'Association des Bibliothécaires Français 1910-1991 (Paris: ABF, 1992), 64.

16. Victor Petrescu, "Apariţia şi dezvoltarea bibliotecilor româneşti (pe actualul teritoriu al României)," in Tratat de biblioteconomie (Bucharest: Librarians Association of Romania), 171-175. 
Later, through the 17th and 18th centuries, rulers and landowners, wealthy people from the high nobility, begin to be interested in books and start setting up private libraries. Nevertheless, this phenomenon did not overcome the aristocratic world. There are a few exceptions, a few attempts to open public libraries. For example, count Samuel Teleki (1739-1822), from Târgu-Mureş, built a construction, especially designed for hosting a library. The library itself was set up by the count's donated collections and it was, from the very beginning, accessible to everyone; it was named "Teleki-teka" (see Figure 3 (a) and (b) for Teleki Libray) and it was open to the public since 1802. An exception will also be made by some academies, the 'College Three Clergymen', or the royal academy in Bucharest, which was set up by Constantin Cantacuzino.
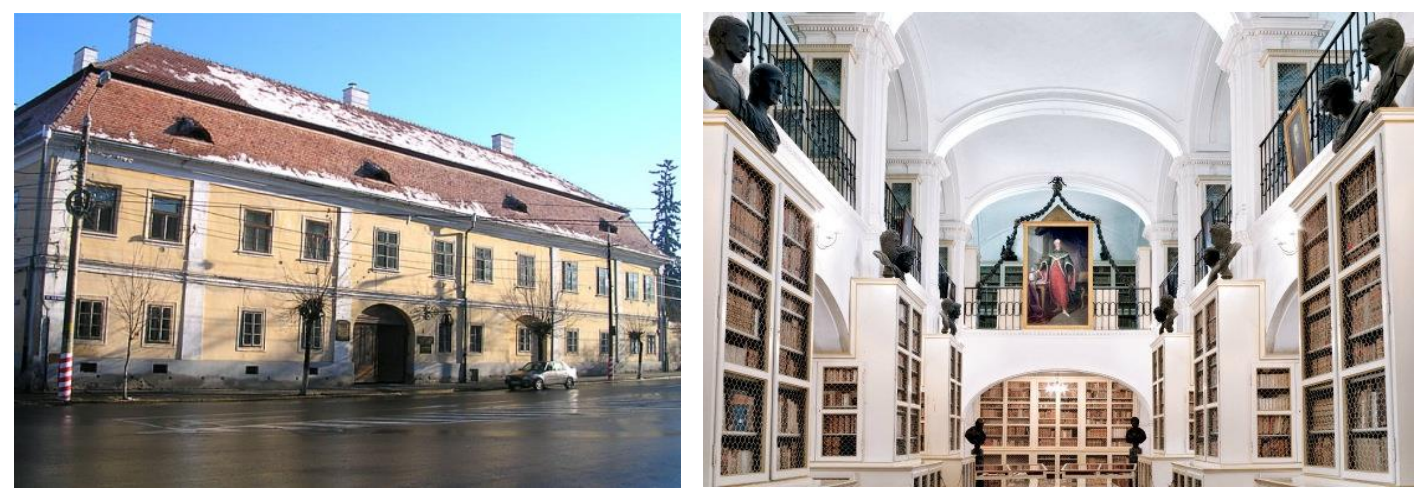

Figures 3. (a) Teleki Library, Târgu-Mureş

Source: http://bit.ly/1RxSbuL.

(b) Teleki Library, Târgu-Mureş, Interior View

Source: http://bit.ly/1Ht3crr.

In the 19th century the appetite for reading to other social classes, like the bourgeois intellectuals, began. Though, the network of public libraries of the country remained modest, despite the efforts of certain associations and cultural foundations, like ASTRA ("Transylvanian Association for Romanian Literature and the Romanian People's Culture"17) or King Carol Cultural Foundation.

With the communists' rise to power (30 December 1947), the desire and the need of imposing a new mentality and political vision, trying the formation of the 'new man' and the political objective of unifying the people of all the country's territories, determined the construction of more municipal and town libraries, and the opening of offices in claimed buildings from private owners, in the period of 1949-1957. The population's access to communist propaganda materials was an essential point in the party's vision. After this period the libraries start to be neglected. ${ }^{18}$

A phenomenon that happened after 1948 was that of censorship. Libraries were, of course, one of the major objectives - there were numerous books of

17. Author's translation.

18. Buluta, Civilizaţia Bibliotecilor, 46-47. 
the libraries were prohibited and this screening process destroyed many school libraries and also libraries connected to the church. Cultural associations and foundations, which played an important role in the country's cultural scene of the time, were dismantled. Since the new government's vision was very strict and imposed strict control, they also wanted a very well controlled system of libraries and therefore a central commission was founded, attached to the Ministry, which stipulated certain measures for improvement of libraries in Romania.

By the '80s, however, libraries will remain far behind the needs of society and their offer will not satisfy the users. Technological progress and intensive industrialization create the need for specialized libraries in industrial enterprises, but in these cases, the attempt of consolidating several specialized libraries in some larger ones will also lead to inefficiency. ${ }^{19}$

After the ' $80 \mathrm{~s}$, there are no more significant library establishments. There is a feeling of discrepancy between the means available and the needs of the libraries, which get more complex with the development of automated calculation of the information society.

The Romanian public still suffers from the reminiscences of the old regime, which was accustomed to the idea of state secrets, secret funds and controlled access to information and classified documents. People are not yet accustomed to freedom of access to information and still ignore the possibilities that public libraries could offer them. Gheorghe Buluta, an important contemporary bibliologist, states: 'We can consider it without fear of being wrong that the Romanian public library remained a closed institution, reserved for a traditional audience, having classical requirements; the library has not been stated yet as a true public information service'. ${ }^{20}$ Often, public libraries serve researchers, in areas where there are few special libraries; they serve pupils and students during exams, when school and university libraries are full. So among frequent users of public libraries one will meet either students, researchers or readers eager to leisure, but rarely one would meet among them "an authorized user who can use the resources of a public library currently, in daily life". 21

There is therefore a matter of perception that comes from library users. They see libraries as static entities, which wait for them and do not go out to meet them. For the library becomes an informational and socializing center, a social pole, open to the community and belonging to the community, the users and librarians will first have to change their perception concerning the library role in their lives and also upgrade their professional skills.

The lack of coherent policies and strategies to guide public library network development and the relative indifference of the authorities will lead to the worsening of public libraries situation, especially of ones located in small and

19. Petrescu, “Apariţia şi dezvoltarea bibliotecilor româneşti (pe actualul teritoriu al României)," 199-200.

20. Doina Banciu, Gheorghe Buluta and Victor Petrescu, Biblioteca şi societatea (Bucharest: Ager Press, 2001), 29.

21. Ibid., 30. 
medium towns. In such locations, these shortcomings feel stronger because, frequently, the libraries are the only entities that have a cultural offer which can generate social coagulation and can strengthen the community spirit and are the only ones that can provide opportunities for training and education.

Further we'll talk about two libraries, one located in the small postindustrial town of Magdeburg, in Germany and the other one, also located in a small post-industrial town, called Turda, in the Transylvanian region of Romania. The first case it is about a reconstructed library, by direct involvement of the community beginning with an event-manifesto. It works in the open air, it is open 24 hours a day and it is managed by users themselves. ${ }^{22}$ In the second case it is about a library like those that we talked about in the beginning of the article, a library that is limited in its activity by lack of space, inadequate architecture, lack of funds and user indifference.

The following comparison wishes to highlight two different situations: one in which the library exists today thanks to the struggle and the direct implications of the local community and the other one, in which the library survives only due to the involvement, devotion and the continuous work of the librarians, who are always trying to pull the community out of indifference. The comparison will thus focus on the different modes of operation of the two libraries, in what concerns the spatiality (one, being an outdoor library, and the other one, being forced to work in a constraint and dysfunctional space) and in what concerns the energies and the driving forces which keep them "alive".

\section{Two Libraries - Two Approaches}

\section{An Open Air Library in Magdeburg, Germany - KARO Architekten and Architektur+Netzwerk}

Some libraries today exceed the boundaries of classical programs of architecture, developing in tandem with community needs to respond to the local problems and to be integrated into an urban tissue in a very particular way, in a discreet and original manner at the same time.

A special case is that of the outdoor library in Magdeburg (see Figure 4 (a) and (b) for open air library in Magdeburg), which is founded at the initiative of local people. It starts with an experiment project called "City in trial", which aims to revitalize the small town, being in the post-industrial decadence, typical for East German suburbs.

The project involved the remembering of the old library that is demolished today. For this a reading and recitation festival that lasted a few days was set up. Thus, on the former library site, on a triangular lot, at the intersection of two major streets, a temporary unconventional library was built. The shelves were made out of beer crates, and the books were brought and donated by the

22. David Bravo Bordas, "Open-Air-Library, Magdeburg (Germany)," public space (April 2015), http://www.publicspace.org/en/works/f084-open-air-library. 
citizens from their own collections. But the result is loved so much by the community, that they will plan the design of a permanent library. ${ }^{23}$

The new library, built between the years of 2008-2009, has covered facades of precast concrete panels, recovered from the recent demolition of a building from the $60 \mathrm{~s} .{ }^{24}$ The walls themselves host in their depth book shelves and niches where one can sit for reading or chatting, and a green space, which can host outdoor readings or other small events and cultural activities. There are also a café and a stage where concerts can be held.

While retaining a modern architectural language, the new library also uses the sensitivity of collective memory and collective imaginary, as its facades are composed of elements taken from a building that no longer exists today. ${ }^{25}$ The intention of preserving the collective memory of an old building and somehow of involving it again in the civic life is the expression of a well-defined community consciousness.

The library is open non-stop, 24 out of 24 hours and is maintained by the residents, based on the civic responsibility of each, so there is no recording or penalty. ${ }^{26}$

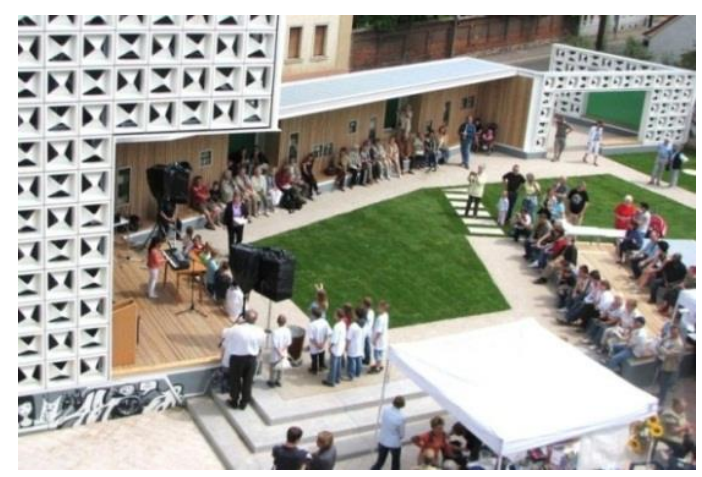

Figure 4. (a), (b) Open Air Library in Magdeburg, Germany - KARO Architekten and Architektur+Netzwerk Source: http://bit.ly/1NtVljX.

In conclusion, it is an aspiring project that transforms an urban space into a library, by removing the need for closures and relying on its opening just by placing it in the way of the people, in the form of a square-plaza. The revitalization or the rebirth of this library is definitely credited to the local community.

\section{A Less “Open” Library in Turda, Romania}

In Romania, the libraries situation is different from that of those in the West, because here we cannot talk about serious investments in the

23. Luiza Hanc, "Bibliotecă în aer liber, Magdeburg,” Igloo, no. 119 (2011): 150-155.

24 . David Bravo Bordas, "Open-Air-Library, Magdeburg (Germany)."

25 . Ibid.

26. "Open Air Library/KARO Architekten," ArchDaily (November 2009), http://bit.ly/ $\underline{1 \mathrm{NtVljX}}$. [Accessed 18 May 2015]. 
modernization and renovation of libraries, much less about the building of new headquarters. There are exceptions of course, but, in general, in our country there were no libraries built after 1989, after the fall of communism. Most often, the buildings housing the libraries in small and medium towns were generally built before 1989, and, most often, these are not buildings designed with this purpose.

There is still, apparently, a foreign interest in the fate of these institutions and so the Bill \& Melinda Gates Foundation has invested 27 million dollars in a program called "Biblionet" which is aimed at ensuring access to information via the computer and Internet. Therefore, many libraries in the country were equipped with internet and computers; their staff has been trained in the use of new technology, so that in turn they can pass on to the public the science of computer use. The project seems really successful, bringing a real change, especially in small communities where the impact of internet access is greater. Paul-Andre Baran, the director of this program in Romania, says that just two years after the start of the project (it started in 2008) there was a 55\% increase in the use of libraries in cities with under 10,000 inhabitants. In medium and large cities, the increase is less spectacular. ${ }^{27}$

Many Romanians declare that Internet access has brought a change in their lives, making them aware of the opportunities for personal and professional achievement or even by relieving them on-line payment services of various bills and taxes. The library looks to slowly become a point of interest, even though there is not an adequate space to support its activities.

However, in our case, as compared to the above example, the community awareness is far from being strong and well defined and the general interest of the citizens of the library remains low.

In Turda city the library is present; it is 'alive' and active and struggles to represent something for the city and citizens. From exhibitions of painting, poetry competitions, a literary circle, projections for children and many others, Turda library opens opportunities for personal and professional development. The Municipal Library is among the few places where Turda's citizens can make contact with cultural life.

The adult section of the library operates in a wing of the building of the Municipal Theatre since its inception in formula it is today. The other sections are: the children's section (operating in an old central building - the former courthouse), and the Branch of "Oprişani", a district of the city (operating in a school's building). ${ }^{28}$ As we can see, none of these sections actually have a space designed for being a library. On the one hand Turda's Library is struggling with the improper spaces, and the relative indifference of the users.

If in the case of the open air library in Magdeburg, the library actually had a place and space of its own, even if it was a public square, in the case of Turda's Library we cannot talk about a space that is actually built for its use. In

\footnotetext{
27. Ioana Mares, "Bill Gates modernizează România cu 27 de milioane de dolari," România Liberă (April 2011), http://bit.ly/1kvxWCP. [Accessed April 4, 2015].

28. "Biblioteca Turda," Biblioteca Turda, http://www.bibliotecaturda.ro. [Accessed April 2015].
} 
the latter case we can say that even the identity image of the library is affected, besides its popularity and attractiveness.

The Turda Library is well aware that to keep pace with the times and to constantly evolve it has to focus increasingly on the intensive use of information technology and to search for answers to the user requirements. But the question would be: how much aware of these transformations are the citizens, users or non-users of the library? Do they feel affected by this fast movement of information and are they aware that the library could help them? Given the information bombardment of nowadays, we think that the library can and should play an important role in our life, being a specialized 'machine' in structuring information and categorizing it, enabling access and the selection of it.

But the most important thing for a library as this one is to constantly improve its image among community and to educate its users in the spirit of social awareness. This way the library should become the heart of civic consciousness and cultural identity.

\section{Conclusions}

Looking at the two examples above, we understand that where the community is involved and interested in the fate of the library, this will live through the energy channeled into it. But where one library is struggling to survive and in general if the community ignores it, it will be very difficult to overcome its condition. On the other hand, library space is a problem as long as it is not the subject of a deep analysis and design process, so as to meet the needs of a proper functionality. We have seen that a library can operate even in the open, if the pavilion architecture is specifically designed to accommodate it.

Libraries have gone through major changes over time, but the present challenge seems to be the most difficult. The technology, the digitization of books and information, the interconnection of world libraries through internet and servers, accessible anywhere in the world from a computer, a tablet or a phone, at home or in vacation, in the city or on a plane or a train, will rise the question whether libraries of the future will need a physical space and the architecture to house books and people? It is our opinion that, as long as people cherish the sharing of information, the dialogue and face-to-face debate, the library space will be sought and desired and communities will find in it a PLACE which shapes the civic spirit and which offers opportunities for personal and intellectual development.

\section{Bibliography}

Banciu, Doina, Gheorghe Buluta and Victor Petrescu. Biblioteca şi societatea [The library and the society]. Bucharest: Ager Press, 2001. 
Bordas, David Bravo. "Open-Air-Library, Magdeburg (Germany).” Public space. http://bit.ly/1OqpZMj [Accessed April 2, 2015].

Brian, Edward and Biddy Fisher. Libraries and Learning Resource Centres. Oxford: Reed Educational and Professional Publishing Ltd, 2002.

Buluta, Gheorghe. Civilizaţia Bibliotecilor. [Libraries Civilization.] Bucharest: Encyclopedic Press, 1998.

. "Apariţia şi dezvoltarea bibliotecilor." [The emergence and development of libraries.] In Tratat de biblioteconomie. Bucharest: Librarians Association of Romania, 2013.

Campbell, James W. P. The Library: A World History. Chicago: University of Chicago Press, 2013.

Eco, Umberto. Numele Trandafirului. [The Name of the Rose.] Bucharest: Polirom Press, 2014.

Habermas, Juergen. The Structural Transformation of the Public Sphere. An Inquiry into a Category of Bourgeois Society. Cambridge: The MIT Press, 1991.

Hanc, Luiza. "Bibliotecă în aer liber, Magdeburg." [Open air library, Magdeburg.] Igloo, 119, (November 2011).

Hecquard, Francoise. La Formation des Bibliothécaires: L'enseignement de l'Association des Bibliothécaires Français 1910-1991. [Training of Librarians: The teaching of French Library Association 1910-1991.] Paris: ABF Press, 1992.

Lerner, Fred. The story of libraries - from the Invention of Writing to the Computer Age. New York: Continuum Press, 2009.

Magne, Nathalie. Henri Lemaître 1881-1946 De la lecture publique á la documentation, Mémoire réalisé sous la direction de Mme Sylvie FAYETSCRIBE. [Henri Lemaitre 1881-1946 From public reading to documentation, Master thesis under the direction of Ms. Sylvie FAYET-SCRIBE.] Paris: Université Panthéon Sorbonne, 1995.

Mares, Ioana. "Bill Gates modernizează România cu 27 de milioane de dolari." [Bill Gates modernizes Romania with 27 million dollars.] România Liberă, (April 2011). http://bit.ly/1RxT7iw [Accessed April 2015].

McCabe, Gerard B. and James R. Kennedy. Planning the modern public library building. Gerard B. McCabe and James R. Kennedy Editors. Libraries Unlimited, 2013.

Petrescu, Victor. "Apariţia şi dezvoltarea bibliotecilor româneşti (pe actualul teritoriu al României)." [The emergence and development of Romanian libraries (the present territory of Romania).] In Tratat de biblioteconomie. Bucharest: Librarians Association of Romania, 2013.

Regneala, Mircea. UNESCO şi accesul mondial la documente şi informaţii. [UNESCO and the global access to documents and informations.] Bucharest: National Institute of Information and Documentation, 1996. 